\title{
Generation of Intracellular Signals by Low Density Lipoprotein Is Independent of the Classical LDL Receptor
}

Agapios Sachinidis, Rudolf Locher, and Wilhelm Vetter

Low density lipoprotein cholesterol (LDL) and apolipoprotein B-100 (1 to $15 \mu \mathrm{g} / \mathrm{mL}$ ) had no significant influence on the inositol-1,4,5-trisphosphate (InsP ${ }_{3}$ ) formation in vascular smooth muscle cells and fibroblasts. Low density lipoprotein cholesterol (15 $\mu \mathrm{g} / \mathrm{mL}$ ) induced an elevation of intracellular $\mathrm{Ca}^{2+}$ from 85 to approximately $210 \mathrm{nmol} / \mathrm{L}$ in vascular smooth muscle cells from rat aorta in the absence or in the presence of $15 \mu \mathrm{g} / \mathrm{mL}$ monoclonal antibodies against the classical low density lipoprotein receptor or in the presence of apolipoprotein B-100. Moreover, in both human cultured fibroblasts from normocholesterolemic individuals and from patients with familial hypercholesterolemia homozygote class 1, LDL induced a dose-dependent rise of free intracellular calcium and a biphasic change of intracellular $\mathrm{pH}$. Since homozygote class 1 fibroblasts are classical LDL receptor negative, and as antibodies against this receptor, as well as apolipoprotein B-100, did not attenuate the LDL-induced elevation of cytosolic calcium, we conclude that LDL might modify vascular activity via the observed intracellular changes without involving the classical low density lipoprotein receptor. Am J Hypertens 1991;4:274-279

KEY WORDS: Low density lipoprotein, vascular muscle cells, fibroblasts, intracellular $\mathrm{Ca}^{2+}$ and $\mathrm{pH}$, phosphatidylinositol turnover.
$\mathrm{R}$ ecently, a correlation between blood pressure and serum cholesterol levels has been described, suggesting that those patients with higher blood pressure values tend to have higher cholesterol levels. ${ }^{1}$ Low density lipoprotein, the major cholesterol-carrying lipoprotein of human plasma, delivers cholesterol to cells by binding to the classical LDL receptors. The cholesterol is then internalized by endocytosis. These receptors recognize the apo-

From the Medical Policlinic, Universtät Bonn, Germany (AS), and Department of Internal Medicine, University Hospital, Zürich, Switzerland (RL, WV).

This work was supported by a fellowship from the Jung-Stiftung for science and research, Hamburg, Germany.

This study is based on data presented at the American Society of Hypertension annual meeting, May 10 to 12, 1989.

Address correspondence and reprint requests to Prof. W. Vetter, MD, Department of Internal Medicine, University Hospital Rämistrasse 100, CH-8091, Zürich, Switzerland lipoprotein B-100 hydrophobic polypeptide. ${ }^{2}$ Low density lipoprotein is considered to be the main atherogenic class of lipoproteins, and contains 60 to $70 \%$ of the total serum cholesterol. Epidemiological and pharmacological studies indicate that the lowering of LDL-cholesterol is accompanied by a decrease in the risk of hypertension. ${ }^{3,4}$ These results suggest that increased LDL-cholesterol levels might modify vascular reactivity in humans with hypercholesterolemia. In addition, vascular smooth muscle cells (VSMC) play a key role in the pathophysiology of both hypertension and atherosclerosis. ${ }^{5,6}$ In order to elucidate cellular mechanisms by which LDL could be involved in the development of hypertension, we demonstrated very recently in cultured VSMC that LDL can induce an elevation of intracellular free $\mathrm{Ca}^{2+}\left(\left[\mathrm{Ca}^{2+}\right]_{\mathrm{i}}\right)$ and a biphasic change of intracellular $\mathrm{pH}\left(\mathrm{pH}_{\mathrm{i}}\right)$ via the $\mathrm{Na}^{+} / \mathrm{H}^{+}$exchanger. In addition, LDL induced vasoconstriction of rat thoracic aortic rings. ${ }^{7}$ 
In the present report, we examined whether these intracellular changes could be mediated by the classical LDL receptor via stimulation of the phosphatidylinositol (Ptlns) turnover, and thus leading to a release of cytosolic calcium. For this purpose, we investigated the effect of LDL in VSMC in the presence of monoclonal LDL receptor antibodies $\left(\mathrm{IgGC}_{7}\right)^{8}$ and apolipoprotein B-100 on the Ptlns turnover as well as on $\left[\mathrm{Ca}^{2+}\right]_{i}$ and $\mathrm{pH}_{\mathrm{i}}$. Moreover, we studied the effect of LDL on $\left[\mathrm{Ca}^{2+}\right]_{\mathrm{i}}$ and $\mathrm{pH}_{\mathrm{i}}$ in LDL receptor negative cultured fibroblasts from patients with familial hypercholesterolemia $(\mathrm{FH})$ homozygote class 1 mutations. Genes from these mutations cannot produce any LDL receptor protein. ${ }^{2}$

\section{MATERIALS AND METHODS}

Materials Fura 2/pentaacetoxymethyl ester (fura 2/ AM) and $\left[2^{\prime}, 7^{\prime}\right.$-bis(carboxyethyl)-5,6-carboxyfluorescein]-pentaacetoxymethyl ester (BCECF/AM) were obtained from Calbiochem (Zürich, Switzerland). Dulbecco's modified Eagles medium (DMEM), Ham's F-10 and Dulbecco's phosphate-buffered saline (PBS) were obtained from Amimed (Zürich, Switzerland). Ethylenglycol-bis-(2-aminoethyl) tetraacetic acid (EGTA), 4-(2-hydroxyethyl)piperazine-1-ethane-sulfonic acid (HEPES) Tris(hydroxymethyl)aminomethane (Trisbase), and other chemicals were obtained from Sigma Chemical (Zürich, Switzerland). Monoclonal low density lipoprotein antibodies as well as myo-[2-3 $\mathrm{H}]$ inositol, and standard $\left[{ }^{3} \mathrm{H}\right]$-Inositolpolyphosphates were obtained from Amersham International, Amersham, Buckinghamshire, England. Normal and Class 1 FH homocygote fibroblasts were obtained from The Human Genetic Mutant Cell Repository Institute for Medical Research, USA.

LDL Isolation Low density lipoprotein (density, 1.019 to $1.063 \mathrm{~g} / \mathrm{mL}$ ) was isolated from the plasma of 5 individual normocholesterolemic subjects (serum cholesterol $<6.2 \mathrm{mmol} / \mathrm{L}$ ) by ultracentrifugation according to Redgrave et al. ${ }^{9}$ The LDL fraction was dialyzed against $0.15 \mathrm{~mol} / \mathrm{L} \mathrm{NaCl} / 1 \mathrm{mmol} / \mathrm{L}$ EDTA, $\mathrm{pH} \mathrm{7.4}$, and used within 3 weeks. Oxidation of LDL was prevented by adding $5 \mu \mathrm{mol} / \mathrm{L}$ butylated hydroxytoluene (BHT) throughout. The LDL was stored at $4^{\circ} \mathrm{C}$ and used within 3 weeks; no changes in activity were observed during this period of time. Determination of protein was performed by Lowry's method. ${ }^{10}$

Culture of Vascular Smooth Muscle Cells Vascular smooth muscle cells were isolated from rat aorta (female, Wistar-Kyoto strain, 6 to 8 weeks old) and recultured several times in accordance with the method of Ross. ${ }^{11}$ The cells were allowed to grow for 4 to 5 days in $5 \% \mathrm{CO}_{2}, 95 \%$ air at $37^{\circ} \mathrm{C}$. The culture medium was Dulbecco's modified Eagle's (DMEM) medium supplemented with $10 \%$ fetal calf serum.
Culture of Fibroblasts Normal and FH homozygote fibroblasts were obtained from the Human Genetic Mutant Cell Repository Institute for Medical Research and recultured several times after detachment of the confluent cells with Puck's Saline A physiological solution containing $0.04 \%$ trypsin $/ 0.02 \%$ EDTA buffer. The cells were allowed to grow as described for the VSMC.

Measurement of Inositolphosphates Cells were seeded in Petri dishes (60 mm diameter) and grew in the presence of myo-[2-3 $\mathrm{H}]$ inositol $(4 \mu \mathrm{Ci} / \mathrm{mL})$ for 3 days. During this time the cells reached confluence. They were washed three times with HEPES buffer, followed by a $2 \mathrm{~h}$ incubation in DMEM without FCS. After 2 other washes with buffer, cells were incubated for 20 min in DMEM containing $20 \mathrm{mmol} / \mathrm{L} \mathrm{LiCl}$ in order to inhibit inositol-1 monophosphatase activity. Then cells were stimulated with LDL for various periods of time. The reactions were terminated by the addition of icecold $8 \%$ trichloroacetic acid (TCA). Samples were kept on ice for $30 \mathrm{~min}$ before removing TCA by extracting the samples with diethyl ether. ${ }^{12}$ Radiolabeled inositol phosphates were analyzed and quantified by standardized anion exchange HPLC. ${ }^{13}$ The $1.25 \mathrm{~mL}$ fractions were transferred to scintillation vials and radioactivity was determined in the liquid scintillation counter. Peak identification of inositol-1-monophosphate, inositol1,4-bisphosphate, and inositol-1,4,5-trisphosphate, were performed by using standard radiolabeled $\left[{ }^{3} \mathrm{H}\right]$ inositol phosphates. Cells were incubated with 1,7 , and $15 \mu \mathrm{g} / \mathrm{mL}$ LDL for different time periods. Positive control experiments were performed by stimulation of the cells with $100 \mathrm{nmol} / \mathrm{L}$ endothelin for different time periods.

Measurement of Free Intracellular $\mathrm{Ca}^{2+}\left[\mathrm{Ca}^{2+}\right]_{\mathbf{i}}$ Confluent cells were detached with $0.04 \%$ trypsin $/ 0.02 \%$ EGTA/Puck's Saline A physiological solution after 5 to $10 \mathrm{~min}$ at $37^{\circ} \mathrm{C}$. Then cells were incubated with $2 \mu \mathrm{mol} /$ $\mathrm{L}$ fura-2 pentaacetoxymethyl ester at $37^{\circ} \mathrm{C}$ for $20 \mathrm{~min}$ in HEPES-buffer $(20 \mathrm{mmol} / \mathrm{L}$ HEPES, $16 \mathrm{mmol} / \mathrm{L}$ glucose, $130 \mathrm{mmol} / \mathrm{L} \mathrm{NaCl}, 1 \mathrm{mmol} / \mathrm{L} \mathrm{MgSO}_{4} \cdot 7 \mathrm{H}_{2} \mathrm{O}, 0.5$ $\mathrm{mmol} / \mathrm{L} \mathrm{CaCl}_{2}$, Tris-base, $\mathrm{pH}, 7.4$ ) supplemented with $1 \%$ bovine serum albumin (BSA). After loading, cells were washed and suspended in HEPES buffer (approximately $2 \times 10^{6}$ cells $/ \mathrm{mL}$ ). The $\mathrm{Ca}^{2+}$-fura- 2 fluorescence was measured at $37^{\circ} \mathrm{C}$ while stirring in a SLM-Aminco SPF-500 (Urbana, IL), spectrofluorometer (excitation wavelengths: 340 and $380 \mathrm{~nm}$; emission: $505 \mathrm{~nm}$ ). Fluorescence was corrected for cellular autofluorescence. Fluorescence signals were calibrated using $0.5 \%$ Triton $\mathrm{X}-100$ for measurement of maximum fluorescence followed by the addition of $2 \mathrm{mmol} / \mathrm{L} \mathrm{MnCl}_{2}$ for minimum fluorescence according to Grynkiewicz et al. ${ }^{14}$ 
Measurement of $\mathrm{pH}_{\mathbf{i}}$ These measurements were performed using the method of Berk et $\mathrm{al}^{15}$ with the fluorescence $\mathrm{pH}$ indicator BCECF. Cells were loaded as described for the fura-2 loading method in HEPES buffer with $2 \mu \mathrm{mol} / \mathrm{L}$ BCECF-pentaacetoxymethyl ester for 20 $\min$ at $37^{\circ} \mathrm{C}$. For the fluorescence measurements the following wavelengths were set: excitation wavelengths: 492 and $438 \mathrm{~nm}$; emission wavelength $525 \mathrm{~nm}$. The calibration curve was performed by permeabilizing the cells with $30 \mu \mathrm{mol} / \mathrm{L}$ digitonin as previously described.

\section{RESULTS}

LDL or Apolipoprotein B-100 Has No Effects on Inositolphosphate Formation In order to investigate whether LDL can stimulate the phosphatidyinositol (Ptlns) turnover, the formation of radiolabeled inositol1 monophosphate $\left(\operatorname{InsP}_{1}\right)$, inositol-1,4-bisphosphate $\left(\mathrm{InsP}_{2}\right)$ and inositol-1,4,5-trisphosphate $\left(\mathrm{InsP}_{3}\right)$ in VSMC was determined by using standardized anion HPLC. Table 1 shows the time-dependency of the myo$\left[{ }^{3} \mathrm{H}\right]$ inositol labeled InsP $\mathrm{P}_{1}, \operatorname{InsP}_{2}$, and $\mathrm{InsP}_{3}$ formation in VSMC resulting from endothelin and LDL stimulation. No significant synthesis of $\operatorname{Ins} \mathrm{P}_{1}, \operatorname{Ins} \mathrm{P}_{2}$, and Ins $\mathrm{P}_{3}$ could be observed after stimulation periods of $20 \mathrm{sec}, 1,3,5$, 10 , and $20 \mathrm{~min}$ with $15 \mu \mathrm{g} / \mathrm{mL}$ LDL or apolipoprotein B-100 compared to the unstimulated cells. Similar results were obtained with 3 and $7 \mu \mathrm{g} / \mathrm{mL} \mathrm{LDL}$ or apolipoprotein B-100. Endothelin induced a strong time-dependent formation of the inositol polyphosphate with a maximum at approximately $10 \mathrm{~min}$. In comparison with unstimulated cells or cells in the presence of $15 \mu \mathrm{g} / \mathrm{mL}$ LDL or apolipoprotein B-100, endothelin caused an approximately 6-, 13-, and 4-fold higher formation of InsP $_{1}$, InsP $P_{2}$, and InsP $P_{3}$ in VSMC, respectively.
Apolipoprotein B-100 or Monoclonal Antibodies Against the LDL Receptor (IgGC ${ }_{7}$ ) Cannot Influence the LDL Induced Elevation of $\left[\mathrm{Ca}^{2+}\right]_{i}$ Apolipoprotein B-100 $(3,7,15 \mu \mathrm{g} / \mathrm{mL})$ had no effects on $\left[\mathrm{Ca}^{2+}\right]_{\mathrm{i}}$. Preincubation of VSMC for $30 \mathrm{~min}$ with $15 \mu \mathrm{g} / \mathrm{mL}$ apolipoprotein B-100 had no effect on the LDL induced release of $\left[\mathrm{Ca}^{2+}\right]_{\mathrm{i}}$. The maximal LDL induced elevation of $\left[\mathrm{Ca}^{2+}\right]_{\mathrm{i}}$, occuring at $20 \mathrm{sec}$, was $212 \pm 19$ in the absence and $208 \pm 21 \mathrm{nmol} / \mathrm{L}$ in the presence of $15 \mu \mathrm{g} / \mathrm{mL}$ apolipoprotein B-100 (mean $\pm S D, n=4$, basal value $70 \pm$ $9 \mathrm{nmol} / \mathrm{L} \mathrm{n}=8$ ). Addition of various concentrations of $\mathrm{IgGC}_{7}$ to VSMC for $30 \mathrm{~min}$ failed to influence $\left[\mathrm{Ca}^{2+}\right]_{\mathrm{i}}$. Preincubation of VSMC for $30 \mathrm{~min}$ with $1,7,35$, and 70 $\mu \mathrm{g} / \mathrm{mL} \mathrm{IgGC}$ at $37^{\circ} \mathrm{C}$, followed by a $15 \mu \mathrm{g} / \mathrm{mL} \mathrm{LDL}$ stimulation did not abolish or reduce the LDL induced elevation of $\left[\mathrm{Ca}^{2+}\right]_{i}$.

LDL Elevates $\left[\mathrm{Ca}^{2+}\right]_{i}$ in Normal and Receptor Negative Fibroblasts Figure 1 shows the concentration-response curve for the maximal LDL induced rise of $\left[\mathrm{Ca}^{2+}\right]_{i}$ at $15 \mathrm{sec}$ in the presence of extracellular $\mathrm{Ca}^{2+}$. Low density lipoprotein concentrations ranging from 1 to $7 \mu \mathrm{g} /$ $\mathrm{mL}$ caused a dose-dependent increase of $\left[\mathrm{Ca}^{2+}\right]_{\mathrm{i}}$. Low density lipoprotein concentrations higher than $7 \mu \mathrm{g} / \mathrm{mL}$ caused no further significant rise of $\left[\mathrm{Ca}^{2+}\right]_{\mathrm{i}}$. Similar results were obtained in normal fibroblasts in both the presence and absence of extracellular $\mathrm{Ca}^{2+}$. As demonstrated in Figure $2 \mathrm{a}, 15 \mu \mathrm{g} / \mathrm{mL}$ LDL induced, in the presence of extracellular $\mathrm{Ca}^{2+}$, a rapid rise in $\left[\mathrm{Ca}^{2+}\right]_{\mathrm{i}}$ (basal value $=73 \pm 8 \mathrm{nmol} / \mathrm{L}$, mean $\pm S D, n=12$ ) with a maximum at $15 \mathrm{sec}$. The rise of LDL induced stimulation of $\left[\mathrm{Ca}^{2+}\right]_{\mathrm{i}}$ declined after $15 \mathrm{sec}$ and reached the resting level within $1.0 \mathrm{~min}$. Low density lipoprotein also stimulated a rapid rise in $\left[\mathrm{Ca}^{2+}\right]_{i}$ in the $\mathrm{Ca}^{2+}$-free buffer (Figure 2b). This rise, however, was less pronounced than in the presence of extracellular $\mathrm{Ca}^{2+}$.

TABLE 1. EFFECT OF LDL AND ENDOTHELIN ON INOSITOLPOLYPHOSPHATES FORMATION IN VSMC (MEAN*)

\begin{tabular}{|c|c|c|c|c|c|c|}
\hline \multirow[b]{2}{*}{ Time (min) } & \multicolumn{3}{|c|}{$\begin{array}{l}\text { Stimulated with } 100 \mathrm{nmol} / \mathrm{L} \\
\text { Endothelin (counts/min) }\end{array}$} & \multicolumn{3}{|c|}{$\begin{array}{l}\text { Stimulated with } 15 \mu \mathrm{g} / \mathrm{mL} \text { LDL } \\
\text { (counts } / \mathrm{min} \text { ) }\end{array}$} \\
\hline & InsP ${ }_{1} \dagger$ & InsP $_{2} \ddagger$ & InsP $_{3} \mathbf{S}$ & InsP $_{1} \dagger$ & $\operatorname{InsP}_{2} \mp$ & InsP $_{3} \mathbf{S}$ \\
\hline 0.0 & 421 & 142 & 62 & 432 & 129 & 66 \\
\hline 0.3 & 398 & 215 & 115 & 415 & 138 & 60 \\
\hline 1.0 & 626 & 725 & 158 & 423 & 142 & 68 \\
\hline 3.0 & 701 & 572 & 148 & 442 & 125 & 57 \\
\hline 6.0 & 1626 & 1219 & 179 & 415 & 132 & 62 \\
\hline 10 & 2507 & 1544 & 246 & 410 & 119 & 64 \\
\hline 15 & 2924 & 1446 & 218 & 390 & 131 & 58 \\
\hline 20 & 3031 & 788 & 138 & 423 & 125 & 62 \\
\hline
\end{tabular}

* Distribution of $S D$ was less than $12 \%$ of the mean $(n=3)$.

$\dagger$ Inositol 1-phosphate; † Inositol 1,4-bisphosphate; § Inositol 1,4,5-trisphosphate. 


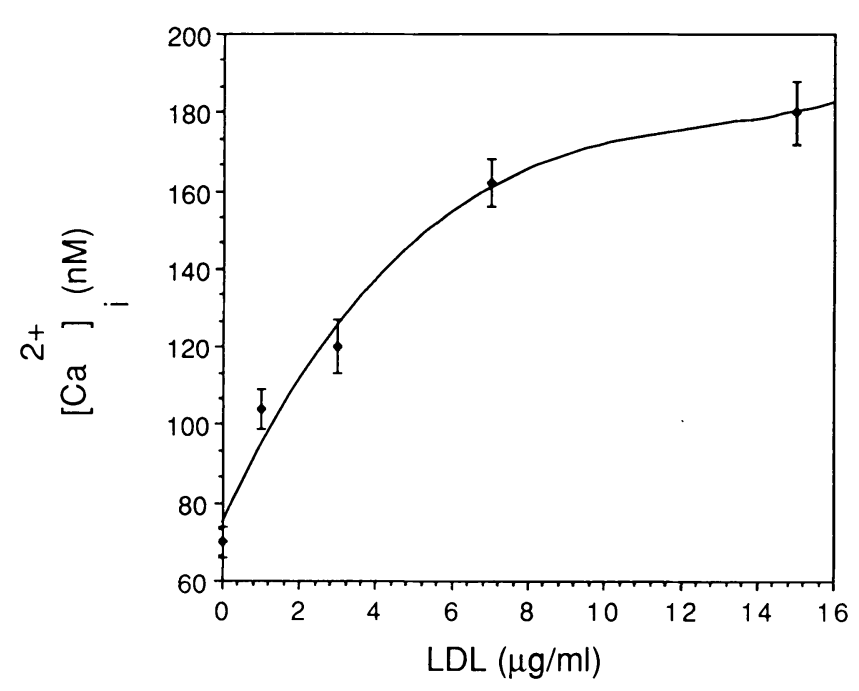

FIGURE 1. Concentration-dependent effect of 1, 3, 7, and 15 $\mu \mathrm{g} / \mathrm{mL} L D L$ on $\left[\mathrm{Ca}^{2+}\right]_{i}$. As $\left[\mathrm{Ca}^{2+}\right]_{i}$ was maximal within $15 \mathrm{sec}$, $\left[\mathrm{Ca}^{2+}\right]_{i}$ obtained at $15 \mathrm{sec}$ stimulations were plotted and given as mean $\pm S D, n=4$.

LDL Changes $\mathrm{pH}_{\mathrm{i}}$ in Normal and Receptor Negative Fibroblasts Figure 3 illustrates the effect of LDL on $\mathrm{pH}_{\mathbf{i}}$ of receptor negative fibroblasts in HEPES buffer. Addition of $7 \mu \mathrm{g} / \mathrm{ml}$ LDL exerted in both cell types a biphasic effect on $\mathrm{pH}_{\mathrm{i}}$ (basal value $=7.04 \pm 0.03, \mathrm{n}=10$ ). Initially, within $2 \mathrm{~min}$ a rapid acidification of $0.06 \pm 0.02$ $(\mathrm{n}=5) \mathrm{pH}$ units occured, followed by a subsequent prolonged alkalinization of $0.12 \pm 0.04 \mathrm{pH}$ units. Similar results were obtained with normal fibroblasts.

\section{DISCUSSION}

Recently, low concentrations of LDL ( 1 to $30 \mu \mathrm{g} / \mathrm{mL}$ ) induced elevation of $\left[\mathrm{Ca}^{2+}\right]_{\mathrm{i}}$ in VSMC were reported. ${ }^{7}$ This elevation was partly due to mobilization of calcium from intracellular stores. In addition, $\mathrm{LDL}$ caused $\mathrm{pH}_{\mathbf{i}}$ shifts in VSMC, probably via activation of $\mathrm{Na}^{+} / \mathrm{H}^{+}$exchange. Furthermore, a mitogenic effect of LDL was also demonstrated. ${ }^{16,17}$ It is recognized that such intracellular changes are mainly triggered by vasoactive agonists, eg, AII or endothelin, or by the receptor-dependent PtIns turnover signal system. ${ }^{18}$ These PtIns turnover-activated intracellular changes are putative signals for cell constriction and cell proliferation and consequently may play an important role in the development of hypertension. ${ }^{19}$ Since LDL showed similar intracellular changes, we examined whether the classical LDL receptor is involved in the elevation of $\left[\mathrm{Ca}^{2+}\right]_{i}$ and $\mathrm{pH}_{\mathrm{i}}$. Surprisingly, our results indicate that these LDL induced intracellular changes are independent of the classical LDL receptor and do not occur via stimulation of the PtIns turnover signal system. These findings are supported by the following observations.

In contrast to endothelin, which caused up to a 5-fold

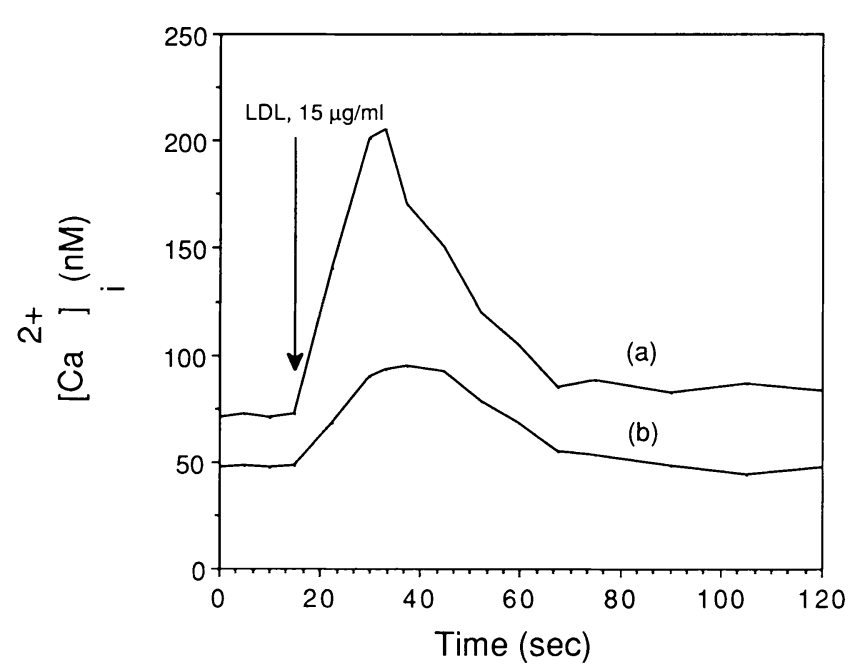

FIGURE 2. Effect of $15 \mu \mathrm{g} / \mathrm{mL}$ LDL on $\left[\mathrm{Ca}^{2+}\right]_{i}$ in cultured human fibroblasts in the presence and absence of extracellular $\mathrm{Ca}^{2+}$. LDL $(15 \mu \mathrm{g} / \mathrm{mL})$ was applied to fura-2-loaded $L D L$ receptor negative fibroblasts in HEPES buffer, containing $1 \mathrm{mmol} / \mathrm{L} \mathrm{CaCl}_{2}$ (a) and in $\mathrm{Ca}^{2+}$-free HEPES-buffer, containing $1 \mathrm{mmol} / \mathrm{L}$ EGTA (b). Changes in fluorescence were monitored for $3 \mathrm{~min}$. After subtraction of autofluorescence, changes in $340 / 380 \mathrm{~nm}$ excitation wavelength ratio by the emission wavelength of $505 \mathrm{~nm}$ were converted into corresponding levels of $\left[\mathrm{Ca}^{2+}\right]_{i}$.

and 25-fold increase of $\operatorname{InsP}_{3}$ and InsP $\mathrm{P}_{2}$ formation, respectively, LDL was not able to stimulate the formation of the PtIns-turnover metabolites $\operatorname{InsP}_{1},-\operatorname{InsP}_{2}$, and InsP $\mathrm{P}_{3}$. Our results are thus in contrast with recent reports ${ }^{20,21}$ showing that low concentrations of LDL induced an net increase of $\operatorname{InsP}_{1}, \operatorname{InsP}_{2}$, and $\operatorname{Ins} \mathrm{P}_{3}$ in VSMC within $10 \mathrm{~min}$. Compared with the strong effects of classical vasoactive agonists on inositol phosphate formation, these increases appear to be of less importance for triggering cellular responses. The differences

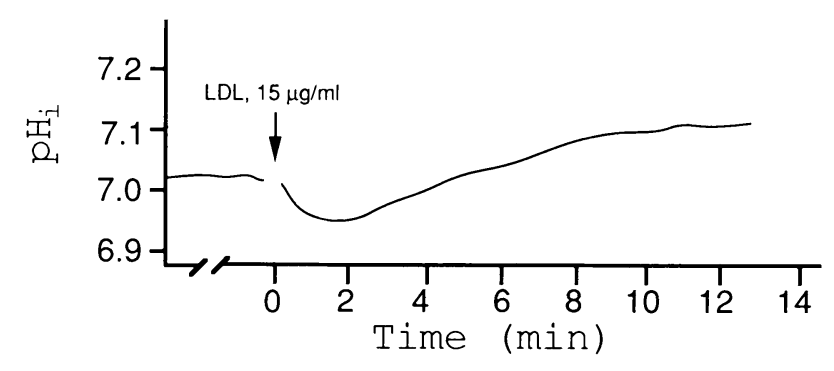

FIGURE 3. Effect of LDL on $\mathrm{pH}_{i}$ in cultured human fibroblasts. $L D L(15 \mu \mathrm{g} / \mathrm{mL})$ was applied to BCECF-loaded LDL receptor negative and normal human fibroblasts. Changes in fluorescence were monitored for $20 \mathrm{~min}$ in HEPES-buffer. After calibration of the fluorescence signal by permeabilizing the cells with $30 \mu \mathrm{mol} / \mathrm{L}$ digitonin, changes in $492 / 438 \mathrm{~nm}$ excitation wavelength ratio by the emission wavelength $525 \mathrm{~nm}$ were converted into corresponding levels of $\mathrm{pH}_{i}$. 
in the results of our study with those of others may reflect VSMC differences, depending on the isolation procedure, strain and age of the animal, cultivation conditions, and number of passages. The much higher sensitivity of the HPLC method in separating inositol phosphates, ${ }^{13}$ compared to the customary method ${ }^{12}$ using Dowex columns, would be another possible explanation for differing reports on the effect of LDL on PtIns turnover.

Preincubation of the VSMC cultures with monoclonal antibodies $\left(\operatorname{IgGC}_{7}\right)^{8}$ against specific surface LDL receptor could not abolish or attenuate the intracellular effects of LDL.

Apolipoprotein B-100, a constituent of LDL, is a hydrophobic polypeptide with a molecular mass of 513 $\mathrm{kDa}$. It facilitates the endocytosis of LDL after binding on the classical LDL receptor. ${ }^{2}$ As shown in our experiments, apolipoprotein B-100 cannot stimulate the formation of inositol polyphosphates. Additionally, preincubation of the VSMC cultures with apolipoprotein B-100 could not affect the LDL induced elevation of $\left[\mathrm{Ca}^{2+}\right]_{\mathrm{i}}$.

Similar LDL-induced changes of $\left[\mathrm{Ca}^{2+}\right]_{\mathrm{i}}$ and $\mathrm{pH}_{\mathrm{i}}$ in normal and receptor negative fibroblasts were observed, indicating that the observed LDL induced intracellular changes are independent of the specific LDL receptor. The lack of LDL to activate PtIns turnover in both cell types is consistent with the former findings.

Since LDL induced an approximately 2 -fold increase of the ${ }^{45} \mathrm{Ca}^{2+}$ influx compared with that in unstimulated cells, ${ }^{17}$ it can be assumed that LDL has some relation to $\mathrm{Ca}^{2+}$ channels. Opening of nonspecific cation channels, which induce depolarization of the membrane and thus trigger the activity of $\mathrm{Ca}^{2+}$ channels, leads to an elevation of $\left[\mathrm{Ca}^{2+}\right]_{\mathrm{i}}$. Low density lipoprotein induced mobilization of $\mathrm{Ca}^{2+}$ from intracellular stores may be brought about by an up to now unknown mediator. One example of such a mediator is GTP, which in pancreatic cells mobilizes $\mathrm{Ca}^{2+}$ from intracellular stores. ${ }^{22}$ According to another report, ${ }^{23}$ indicating that an influx of extracellular $\mathrm{Ca}^{2+}$ mobilized the release of $\mathrm{Ca}^{2+}$ from the sarcoplasmic reticulum in VSMC, the possibility exists that the LDL induced release of $\mathrm{Ca}^{2+}$ from intracellular stores may be triggered by a similar mechanism. Our results do not exclude the existence of another LDL receptor in VSMC or fibroblasts. A nonclassical LDL receptor, the "scavenger receptor" has been described in monocyte/ macrophages and endothelial cells. This receptor recognizes and takes up modified LDL at a rate many times higher than native LDL. ${ }^{24}$

From our findings two principal questions arise: Is the isolated LDL native or modified? Although isolation of LDL was performed in the presence of the antioxidants BHT or ascorbic acid, a minimized oxidation of LDL cannot be excluded. Are there any artifactual LDL adherent factors causing the observed intracellular changes? After LDL precipitation by $70 \%$ ethanol no activity in the $70 \%$ ethanol supernatant was found (unpublished observation) indicating that the observed intracellular changes were not induced by adherent factors with a small molecular mass. However, nondialyzable factors cannot be excluded and it is conceivable that these putative factors have stimulatory effects only in association with the LDL particle.

Although the real concentrations of LDL in the extracellular fluid are unknown, experiments on the LDL clearance in several tissues indicate that LDL can occur in the extracellular space. ${ }^{25,26}$ The relatively low in vitro concentrations of LDL triggering the aforementioned cellular events probably correspond to in vivo concentrations of LDL in extravascular fluids. These LDL concentrations are much lower than those in plasma due to the diffusion barrier offered by vascular endothelium. In addition, there are fluctuations in LDL concentrations due to dietary, ${ }^{27}$ physiological, ${ }^{28}$ and pharmacological manipulation. ${ }^{29}$ In addition, binding and uptake of LDL have been observed following incubation of cultured rat VSMC with $10 \mu \mathrm{g} / \mathrm{mL}$ of homologous LDL. ${ }^{30,31}$

In conclusion, our findings suggest that LDL, apart from its physiological function as a cholesterol transport molecule, can also contribute to the pathogenesis of cardiovascular diseases by elevating $\left[\mathrm{Ca}^{2+}\right]_{\mathrm{i}}$ and $\mathrm{pH}_{\mathrm{i}}$. Consequently, in humans with hypercholesterolemia, LDLcholesterol might modify vascular reactivity without involving the specific LDL receptor.

\section{REFERENCES}

1. Castelli WP, Anderson K: A population at risk. Prevalence of high cholesterol levels in hypertensive patients in the Framingham Study. Am J Med 1986;80:(suppl 2A) 23-32.

2. Brown SM, Goldstein LJ: A receptor-mediated pathway for cholesterol homeostasis. Science 1986;232:34-37.

3. Ekelund LG, McMahon RP, Whaley FS, et al: Does lowering of cholesterol with cholestyramine decrease the incidence of hypertension in hypercholesterolemic men. The LRC Coronary Primary Prevention Trial. CVD Epidemiology Newsletter 1988;43.

4. Ekelund LG: Lowering lipids and the genesis of hypertension. Drugs 1988;36(suppl 32):21.

5. Schwartz SM, Campbell GR, Campbell JH: Replication of smooth muscle cells in vascular disease. Circ Res 1986; 58:427-444.

6. Ross RJ, Glomset JA: Atherosclerosis and arterial smooth muscle cell. N Engl J Med 1976;295:369-377.

7. Sachinidis A, Locher R, Mengden T, et al: Vasoconstriction: a novel activity for low-density lipoprotein. Biochem Biophys Res Commun 1989;163:315-320.

8. Beisiegel U, Schneider WJ, Goldstein JL, et al: Monoclonal antibodies to the low density lipoprotein receptor as probes for study of receptor-mediated endocytosis and the genetics of familial hypercholesterolemia. J Biol Chem 1981;256:11923-11931. 
9. Redgrave TG, Robert DCK, West CE: Separation of plasma lipoproteins by density-gradient ultracentrifugation. Anal Biochem 1975;65:42-49.

10. Lowry OH, Rosebrough NH, Farr AL, Randall RJ: Protein measurements with the folin phenol reagent. J Biol Chem 1951;193:265-275.

11. Ross RJ: The smooth muscle cell II. Growth of smooth muscle in culture and formation of elastic fiber. J Cell Biol 1971;50:172-182.

12. Berridge MJ, Dawson RMC, Downes CP, et al: Changes in the levels of inositol phosphates after agonist-dependent hydrolysis of membrane phosphoinositides. Biochem J 1983;212:473-482.

13. Irvine RF, Anggard EE, Letcher AJ, Downes P: Metabolism of inositol 1,4,5-trisphosphate and inositol 1,3,4trisphosphate in rat parotid glands. Biochem J 1985; 229:505-511.

14. Grynkiewicz G, Poenie M, Tsien RY: A new generation of $\mathrm{Ca}^{2+}$ indicators with greatly improved fluorescence properties. J Biol Chem 1985;260:3440-3450.

15. Berk BC, Aronow MS, Brock TA, Angiotensin II-stimulated $\mathrm{Na}^{+} / \mathrm{H}^{+}$exchange in cultured vascular smooth muscle cells. J Biol Chem 1987;262:5057-5064.

16. Oikawa S, Hori S, Sano R, et al: Effect of low density lipoprotein on DNA synthesis of cultured human arterial smooth muscle cells. Atherosclerosis 1986;64:7-12.

17. Sachinidis A, Mengden T, Locher R, et al: Novel cellular activities for low-density lipoprotein in vascular smooth muscle cells. Hypertension 1990;15:704-711.

18. Berridge MJ, Irvine RF: Inositol trisphosphate, a novel second messenger in cellular signal transduction. Nature 1984;312:315-321.

19. Heagerty AM, Ollerenshaw JD: The phosphoinositide signalling system and hypertension. J Hypertens 1987; 5:515-524.

20. Scott-Burden T, Resink TJ, Hahn AWA, et al: Induction of growth-related metabolism in human vascular smooth muscle cells by low density lipoprotein. J Biol Chem 1989;264:12582-12589.
21. Block LH, Knorr M, Vogt E, et al: Low density lipoprotein causes general cellular activation with increased phosphatidylinositol turnover and lipoprotein catabolism. Proc Natl Acad Sci USA 1988;85:885-889.

22. Muallem S, Beeker TG: Relationship between hormonal, GTP and Ins $(1,4,5) \mathrm{P}_{3}$-stimulated $\mathrm{Ca}^{2+}$ uptake and release in pancreatic acinar cells. Biochem J 1989;263:333 339.

23. Goldman WF, Bova S: An influx of extracellular $\mathrm{Ca}^{2+}$ mobilizes $\mathrm{Ca}^{2+}$ from a caffeine-sensitive intracellular store in vascular smooth muscle cell line. Hypertension 1989;14:331.

24. Steinberg D, Parthasarathy S, Carew ET, et al: Modification of low-density lipoprotein that increase its atherogenicity. N Engl J Med 1989;320:915-924.

25. Reichl D, Simons LA, Myant NB, et al: The lipids and lipoprotein of human peripheral lymphocytes, with observation on the transport of cholesterol from plasma and tissues into lymphocytes. Clin Sci Mol Med 1973; 45:313-329.

26. Spady DK, Bilheimer DW, Dietschy JM: Rates of receptor-dependent and independent low density lipoprotein uptake in the hamster. Proc Natl Acad Sci USA 1983; 80:3499-3503.

27. Weisweiler $P$, Drosner $M$, Janetschek $P$, Schwandt $P$ : Changes in very low and low density lipoproteins with dietary fat modification. Atherosclerosis 1983;49:325332.

28. Miller NE: Why does plasma low density lipoprotein concentration in adults increase with age? Lancet 1984; i:263-266.

29. Ohata I, Sakamoto N, Nagano K, Maeno H: Low density lipoprotein-lowering and high density lipoprotein-elevating effects of nicardipine in rats. Biochem Pharmacol 1984;33:2199-2205.

30. Bierman EL, Stein O, Stein Y: Lipoprotein uptake and metabolism by rat aortic smooth muscle cells in tissue culture. Circ Res 1974;35:136-150.

31. Kuehl KS, Holloway PW: Lipoprotein uptake by vascular smooth muscle cells. Cell Tissue Res 1983;233:453-462. 